\title{
Evaluating Fluid-Host post entrapment interaction in UHP fluid inclusions
}

\author{
MAFFEIS ANDREA ${ }^{1}$, FERRANDO SIMONA ${ }^{1}$, CASTELli \\ DANIELE $^{1}$, GROPPO CHIARA ${ }^{1}$, FREZZOTTI MARIA LUCE ${ }^{2}$ \\ ${ }^{1}$ Universitàdegli Studi di Torino (andrea.maffeis@unito.it) \\ ${ }^{2}$ Università degli Studi di Milano - Bicocca
}

Fluid inclusions (FI) are the only direct way to sample fluids, including the C-bearing ones relevant to investigate the Deep Carbon Cycle [1], circulating during active subduction of continental crust at sub-arc depth. The main difficulty of the FI study lays in the identification of the most preserved inclusions, e.g. those lacking chemical posttrapping re-equilibration with the host mineral. In the ultrahigh pressure (UHP) Brossasco-Isasca Unit of the DoraMaira Massif, there are impure marbles lenses that experienced peak metamorphic conditions at $\sim 4.3 \mathrm{GPa}$ and $\sim 730^{\circ} \mathrm{C}$ [2] and multiple events of prograde-to-earlyretrograde UHP dissolution-precipitation of dolomite [3].

Detailed petrographic investigation of the chemically simple impure marble allows to distinguish five main FI generations within zoned Di. The generation trapped at UHP conditions consists of primary tri-phase $(\mathrm{S}+\mathrm{L}+\mathrm{V})$ multisolid aqueous FI. Micro-Raman analysis allowed to recognize four subtypes (Ia, Ib, Ic, Id), depending on the fluid content and the included mineral assemblage: Ia) $\mathrm{Mg}$ $\mathrm{Cc}+\mathrm{H}_{2} \mathrm{O}_{L}+\mathrm{H}_{2} \mathrm{O}_{V}+\mathrm{N}_{2}$; Ib) $\mathrm{H}_{2} \mathrm{O}_{\mathrm{L}}+\mathrm{Mg}-\mathrm{Cc}+\mathrm{Tlc}+\mathrm{H}_{2} \mathrm{OV}+\mathrm{N}_{2}$; Ic) $\mathrm{Mg}-\mathrm{Cc} / \mathrm{Cc}+\mathrm{Atg}+\mathrm{Ctl}+\mathrm{Tlc} \pm \mathrm{Tr} \pm \mathrm{Dol}+\mathrm{H}_{2} \mathrm{O}_{\mathrm{L}}+\mathrm{H}_{2} \mathrm{OV}+\mathrm{N}_{2}$; Id) $\mathrm{Mg}-$ $\mathrm{Cc} / \mathrm{Cc}+\mathrm{Atg}+\mathrm{Ctl}+\mathrm{Tlc}+\mathrm{Dol} \pm \mathrm{Tr}$. SEM-EDS qualitative analyses on opened FI also revealed the presence of chlorides $(\mathrm{NaCl}$, $\mathrm{KCl}$ ) and $\mathrm{Fe}$-sulphides.

Thermodynamic modelling in the system $\mathrm{CMS}-\mathrm{H}_{2} \mathrm{O}-\mathrm{CO}_{2}$ allowed the identification of possible post-entrapment reactions between the host $\mathrm{Di}$ and the solute rich aqueous fluid. This allowed to recognize that Ib-Id FI subtypes represent stages of progressive FI chemical re-equilibration with the host, whereas Ia FI subtype contain incidentally trapped carbonates. These data indicate the presence, at UHP conditions, of a $\mathrm{COHN}$ electrolytic fluid (i.e., not a $\mathrm{COHN}$ molecular fluid) containing dissolved $\mathrm{Ca}+\mathrm{Mg}+\mathrm{Si}$, and minor $\mathrm{Fe}+\mathrm{Na}+\mathrm{K}+\mathrm{Cl}+\mathrm{S}$. Image analyses and Micro-Raman maps allowed to estimate the fluid bulk composition from the most preserved FI (subtype Ia).

[1] Kelemen \& Manning, (2015) P Natl Acad Sci USA, 112(30), E3997-E4006.

[2] Castelli et al. (2007): J Metamorph Geol., 25(6), 587603.

[3] Ferrando et al. (2017): Am. Mineral., 102(1), 42-60 